Number 2

\title{
ANALISIS TOTAL FENOL PADA BERBAGAI FORMULASI REBUSAN KULIT SALAK BALI SIBETAN KARANGASEM SEBAGAI MINUMAN FUNGSIONAL
}

I DG Aditya Satria Darma Putra ${ }^{1}$, I Wayan Merta ${ }^{2}$, Cok Dewi Widhya Hana Sundari ${ }^{3}$

\begin{abstract}
Background: Snakefruit's rind that only so far as waste, can be processed into a functional beverage is good for health. Snakefruit's bark contains phenolic compounds which are natural antioxidants in fruits.

Objective: The purpose of this study is to determine the total phenol levels and sensory value of stew salak bali sibetan karangasem's bark in various formulations as functional beverage. Methods: Analysis of total used spectrophotometric method with Folin-Ciocalteu phenol reagent and gallic acid standard. It also performed the water content analysis used thermogravimetry method.

Result: Salak Bali Sibetan's bark have average water content $24.1872 \pm 0.036 \%$ wb. The results of total phenol analysis showed that 2, 10, 20, 30, 40 gram of Salak Bali's bark with $200 \mathrm{ml}$ water are: 10,84 $\pm 0,587 ; 13,79 \pm 0,756 ; 12,19 \pm 0,205 ; 12,02 \pm 0,268 ; 10,57 \pm 0,389 \mathrm{mg} / \mathrm{L}$ GAE respectirely. Conclusions: The highest total phenol content is $(10 \mathrm{~g} / 200 \mathrm{ml})$ formulation, and also supported by a sensory test showed that a majority of panelist also prefer that formulation because has good colour, flavor and smell.
\end{abstract}

Keywords : Salak Bali’s Sibetan rind, total phenol, Folin-Ciocalteu.

\section{PENDAHULUAN}

Salak (Salacca zalacca) merupakan tanaman asli Indonesia. Di Indonesia dikenal antara 20 sampai 30 jenis spesies salak. Beberapa yang terkenal diantaranya adalah salak Sidimpuan dari Sumatra Utara, salak pondoh dari Yogyakarta, salak condet dari DKI jakarta, dan salak Bali ${ }^{1}$. Buah salak mengandung berbagai senyawa yang dapat berperan sebagai antioksidan, diantaranya vitamin $C$, likopen serta $\beta$ - karoten yang merupakan provitamin A, asam asam organik, senyawa fenolik serta $\operatorname{tanin}^{2,3}$. Senyawa fenolik bersifat sebagai antioksidan karena kemampuannya melawan pembentukan radikal bebas dalam tubuh.

1.,2.,3., Jurusan Analis Kesehatan Poltekkes Denpasar Korespondensi : Ni Wayan Nia Ariska Purwanti ${ }^{1}$, Jurusan Analis Kesehatan, Poltekes Denpasar, Jalan Sanitasi No. 1 Sidakarya, Denpasar-Bali 80224, Indonesia.

Telp. +62-361-710 527, Fax. +62-361-710 448

Email : meditoryjournal@gmail.com 
Banyak penelitian telah menunjukkan bahwa buah-buahan dan sayuran yang kaya polifenol sangat efektif dalam melindungi tubuh dari penyakit kanker, kardiovaskular, dan gangguan saraf ${ }^{4}$. Beberapa senyawa polifenol juga diketahui mempunyai aktivitas antihipertensi ${ }^{5}$. Buah salak diketahui memiliki total polifenol yang lebih tinggi dari pada buah manggis (Garcinia mangostana) ${ }^{6}$. Salak Bali memiliki kadar fenolik total lebih tinggi di bandingkan dengan salak pondoh dan salak ngelumut yaitu $6,43 \pm 1,21 \mathrm{mg} / \mathrm{kg} \mathrm{db}{ }^{7}$.

Desa Sibetan Kecamatan Bebandem merupakan salah satu sentra penghasil buah salak di Kabupaten Karangasem. Mayoritas jenis salak yang dikembangkan oleh petani di desa ini adalah salak "Sibetan" yang lebih dikenal dengan sebutan salak Bali. Kelebihan salak Bali adalah memiliki biji yang kecil sehingga daging buah lebih tebal, rasa yang manis dan renyah ${ }^{8}$. Saat musim panen tiba selain dijual langsung, untuk meminimalisir kerugian warga desa tersebut memiliki inisiatif meracik dan mengolah buah-buah tersebut menjadi beberapa olahan seperti wine, dodol, kripik, sirup dan manisan ${ }^{9}$. Cara-cara seperti ini sangat diperlukan selain untuk mengurangi kerugian, juga untuk meningkatkan daya jual dari buah salak tersebut.
Selama ini salak dianggap sebagai buah-buahan yang hanya dapat dinikmati buahnya saja. Tidak hanya itu, kulit buah salak dianggap hanya sebagai limbah dan tidak termanfaatkan. Penelitian penelitian tentang kandungan kulit salak banyak di lakukan. Hasil uji fitokimia menunjukkan kulit buah salak mengandung senyawa flavonoid dan tannin serta sedikit alkaloid. Kandungan flavonoid di dalam ekstrak kulit salak mampu menurunkan kadar glukosa dalam darah ${ }^{10}$. Tingkat kekuatan antioksidan pada air rebusan kulit salak tergolong aktif karena berada pada rentangan $50-100 \mathrm{ppm}^{11}$.

Antioksidan sangat bermanfaat bagi kesehatan yaitu dapat mencegah pemicu penyakit regeneratif seperti : kanker, diabetes, penuaan dini yang disebabkan oleh radikal bebas dan antioksidan juga dapat mempertahankan mutu produk pangan ${ }^{12}$. Bahan alam memiliki potensi aktivitas biologis sebagai antioksidan dan antikanker karena strukturnya memiliki gugus fenol ${ }^{13}$. Fenol merupakan senyawa kimia yang alami terkandung di dalam tumbuhan, bersifat sebagai antioksidan kuat dan umumnya banyak terkandung pada kulit buah ${ }^{14}$.

Berdasarkan uji pendahuluan yang telah dilakukan menggunakan reagen Folin-Ciocalteu phenol, saat rebusan kulit salak direaksikan dengan reagen tersebut 
terjadi perubahan warna menjadi biru yang menandakan bahwa rebusan kulit salak mengandung senyawa fenol. Formulasi yang digunakan dalam uji pendahuluan ini adalah 40 gram kulit salak dengan $200 \mathrm{ml}$ air. Hasil air rebusan yang didapatkan sudah cukup pekat, maka perlu dilakukan penelitian dengan formulasi dibawahnya dan dibatasi hingga formulasi tersebut agar penambahan kulit salak tidak terlalu banyak. Berdasarkan uraian di atas maka peneliti tertarik dan ingin melakukan penelitian mengenai analisis total fenol pada berbagai formulasi rebusan kulit salak Bali Sibetan Karangasem yang dapat di aplikasikan sebagai minuman fungsional.

\section{METODE}

Jenis penelitian yang digunakan adalah pra eksperimen dengan rancangan Posttest Only Design. Dalam rancangan ini perlakuan atau intervensi telah dilakukan (X) kemudian dilakukan pengukuran (observasi) atau posttest (02). Hasil observasi hanya memberikan informasi yang bersifat deskriptif. Dalam rancangan ini tidak terdapat kontrol ${ }^{15}$.Penelitian ini dilakukan pada bulan Februari sampai Juni 2016 di Agrowisata milik Kelompok Tani Abian Salak Desa Sibetan Kecamatan Bebandem Kabupaten Karangasem untuk pengambilan sampel salak. Pemeriksaan dilakukan pada Laboratorium Kimia
Jurusan Analis Kesehatan Poltekkes Denpasar untuk menguji kadar air dan total fenol kulit salak.

Cara pengambilan sampel dengan purposive sampling, yaitu suatu teknik penetapan sampel dengan cara memilih sampel sesuai dengan kriteria sampel. Cara pengumpulan data yang digunakan dalam penelitian ini adalah observasi, uji subjektif (warna, rasa, aroma, dan penerimaan keseluruhan) serta analisis laboratorium kadar total fenol pada berbagai formulasi rebusan kulit salak menggunakan metode spektrofotometer dengan reagen Folin-Ciocalteu phenol. Setelah mendapatkan data, data diolah dengan statistik deskriptif yaitu statistik yang berfungsi untuk mendeskripsikan atau memberi gambaran terhadap objek yang diteliti melalui data sampel atau populasi sebagaimana adanya ${ }^{16}$.

\section{HASIL DAN PEMBAHASAN}

\section{Hasil :}

\section{Hasil pemeriksaan total fenol}

Analisis total fenol yang dilakukan dalam penelitian ini menggunakan spektrofotometer pada panjang gelombang $760 \mathrm{~nm}$ dan dengan menggunakan reagen Folin-Ciocalteu phenol. Hasil dari pengukuran absorbansi larutan standar asam galat yang telah diplot dalam kurva absorbansi standar dapat dilihat pada Gambar 1. 


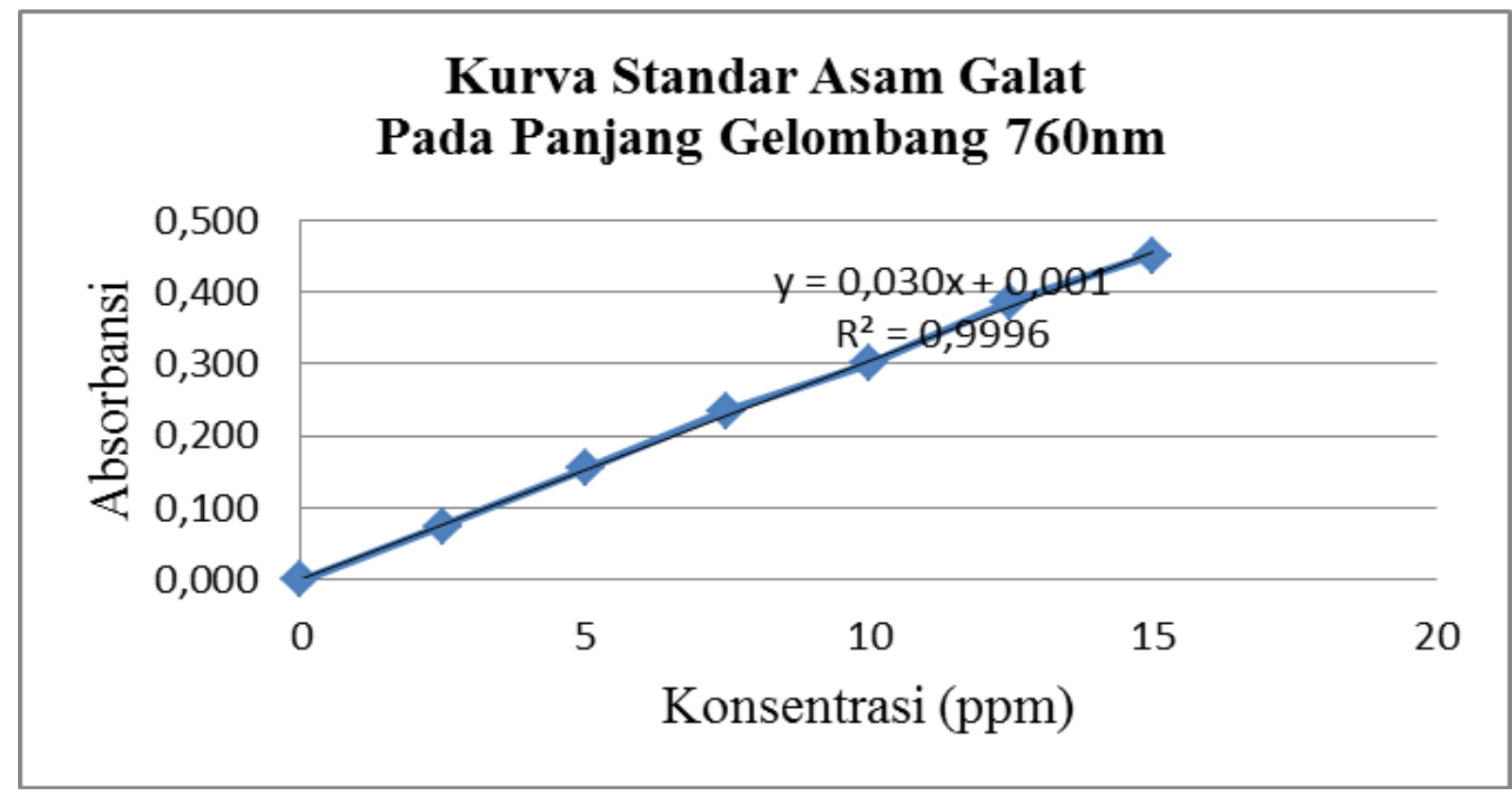

Gambar 1.

\section{Kurva Standar Asam Galat}

Hasil dari pemeriksaan total fenol pada berbagai formulasi rebusan kulit salak yang diperiksa menggunakan metode spektrofotometri dengan reagen reagen
Folin-Ciocalteu phenol dapat dilihat pada Tabel 1.

Tabel 1. Total Fenol Pada Berbagai Formulasi Rebusan Kulit Salak Bali Sibetan

\begin{tabular}{|c|c|c|c|}
\hline \multirow{2}{*}{ Formulasi } & \multicolumn{3}{|c|}{ Total Fenol (mg/L GAE) } \\
\cline { 2 - 4 } & Replikasi & Replikasi & Rata rata \& SD \\
& 1 & $\mathbf{2}$ & \\
\hline 2 gram kulit salak : $200 \mathrm{ml}$ air & 10.42 & 11.25 & $10.84 \pm 0.587$ \\
\hline 10 gram kulit salak : $200 \mathrm{ml}$ air & 13.25 & 14.32 & $13.79 \pm 0.756$ \\
\hline 20 gram kulit salak : $200 \mathrm{ml}$ air & 12.04 & 12.33 & $12.19 \pm 0.205$ \\
\hline 30 gram kulit salak : $200 \mathrm{ml}$ air & 11.83 & 12.21 & $12.02 \pm 0.268$ \\
& & & $10.57 \pm 0.389$ \\
\hline 40 gram kulit salak : $200 \mathrm{ml}$ air & 10.29 & 10.84 & \\
\hline
\end{tabular}



KULIT SALAK BALI SIBETAN KARANGASEM SEBAGAI MINUMAN FUNGSIONAL

Tabel 1 menunjukkan hasil dari perhitungan total fenol yang telah dilakukan, nilai rata-rata total fenol tertinggi adalah pada formulasi 10gram dengan $200 \mathrm{ml}$ yaitu $13.79 \pm 0.756 \mathrm{mg} / \mathrm{L}$ GAE dan kadar terendahnya adalah pada formulasi 40gram dengan $200 \mathrm{ml}$ yaitu $10.57 \pm 0.389 \mathrm{mg} / \mathrm{L}$ GAE. Pada formulasi 2 gram hanyak mampu menghasilkan total fenol $10.84 \pm 0.587 \mathrm{mg} / \mathrm{L}$ GAE. Terjadi penurunan kadar total fenol pada formulasi 20 gram hingga 40 gram.

\section{Hasil uji organoleptik berbagai formulasi rebusan kulit salak}

Digunakan panelis sebanyak 25 orang di Jurusan Analis Kesehatan Poltekkes Denpasar untuk menguji secara sensori formulasi air rebusan kulit salak. Adapun kriteria penilaian dalam penelitian kali ini adalah warna, rasa, aroma dan penerimaan keseluruhan disajikan pada Tabel 2.

\section{Pembahasan}

Polifenol adalah sekelompok zat kimia yang secara alami ditemukan pada tumbuhan. Zat ini memiliki tanda khas yakni memiliki banyak gugus fenol didalam molekulnya. Komponen senyawa fenolik bersifat polar dan memiliki fungsi antara lain sebagai penangkap radikal bebas dan peredam terbentuknya oksigen singlet. Pada beberapa penelitian, disebutkan bahwa kelompok polifenol memiliki peran sebagai antioksidan yang baik untuk kesehatan. Antioksidan dari senyawa ini dapat mengurangi beberapa risiko penyakit seperti serangan jantung dan kanker ${ }^{14}$.

Berdasarkan hasil pengujian kadar air dengan menggunakan metode pemanasan langsung (direct heating) menggunakan oven, didapatkan bahwa kulit salak Bali Sibetan mengandung ratarata kadar air $24.1872 \%$ bb \pm 0.036 . Berbeda jenis salak tentunya berbeda juga kadar air dari kulit salak tersebut. Adapun berdasarkan hasil penelitian kadar air kulit salak Pondoh yaitu $74.67 \%$ dan kulit salak Gading yaitu $30.06 \%{ }^{17}$. Maka dari itu kulit salak Bali Sibetan memiliki kadar air yang lebih rendah dibandingkan salak Gading dan Pondoh. Kadar air dalam suatu bahan sangat perlu diuji karena tingginya kadar air menjadi faktor mudahnya suatu komoditi mengalami kerusakan dikarenakan bakteri, kapang, khamir mudah berkembang ${ }^{18}$. 
Tabel 2. Hasil Rekapitulasi Data Uji Organoleptik Air Rebusan Kulit Salak

\begin{tabular}{|c|c|c|c|c|c|c|c|c|c|c|c|}
\hline \multirow{3}{*}{$\begin{array}{c}\text { Kriteria } \\
\text { Penilaian }\end{array}$} & \multicolumn{10}{|c|}{ Formulasi } & \multirow{3}{*}{$\begin{array}{c}\text { Total } \\
\text { responden }\end{array}$} \\
\hline & \multicolumn{2}{|c|}{$\begin{array}{c}(1) \\
2 \mathrm{~g} / 200 \mathrm{ml}\end{array}$} & \multicolumn{2}{|c|}{$\begin{array}{c}(2) \\
10 \mathrm{~g} / 200 \mathrm{ml}\end{array}$} & \multicolumn{2}{|c|}{$\begin{array}{c}(3) \\
20 \mathrm{~g} / 200 \mathrm{ml}\end{array}$} & \multicolumn{2}{|c|}{$\begin{array}{c}(4) \\
30 \mathrm{~g} / 200 \mathrm{ml}\end{array}$} & \multicolumn{2}{|c|}{$\begin{array}{c}5) \\
40 \mathrm{~g} / 200 \mathrm{ml}\end{array}$} & \\
\hline & Suka & $\begin{array}{l}\text { Tidak } \\
\text { suka }\end{array}$ & Suka & $\begin{array}{c}\text { Tidak } \\
\text { suka }\end{array}$ & Suka & $\begin{array}{c}\text { Tidak } \\
\text { suka }\end{array}$ & Suka & $\begin{array}{c}\text { Tidak } \\
\text { suka }\end{array}$ & Suka & $\begin{array}{c}\text { Tidak } \\
\text { suka }\end{array}$ & \\
\hline Warna & 4 & 21 & 20 & 4 & 1 & 21 & 0 & 25 & 0 & 25 & \\
\hline Rasa & 7 & 18 & 16 & 9 & 2 & 23 & 0 & 25 & 0 & 25 & \\
\hline Aroma & 4 & 21 & 16 & 9 & 3 & 22 & 0 & 25 & 2 & 23 & 25 orang \\
\hline $\begin{array}{l}\text { Penerimaan } \\
\text { keseluruhan }\end{array}$ & 3 & 22 & 20 & 5 & 2 & 23 & 0 & 23 & 0 & 25 & \\
\hline
\end{tabular}

\section{Keterangan :}

- Formulasi yang paling banyak diminati panelis baik dari segi warna, rasa, aroma dan penerimaan keseluruhan adalah formulasi ke $2(10 \mathrm{gram} / 200 \mathrm{ml})$

Berdasarkan hasil pengujian analisis total fenol yang telah dilakukan, formulasi yang memiliki nilai total fenol tertinggi adalah formulasi ke 2 yaitu $13.79 \pm 0.756$ $\mathrm{mg} / \mathrm{L}$ GAE. Formulasi tersebut dibuat dengan kandungan 10 gram kulit salak. Hasil ini lebih tinggi jika dibandingankan dengan hasil penelitian menggunakan 10 gram daging buah salak Bali yang memiliki nilai total fenol sebesar 6.43 $\mathrm{mg} / \mathrm{kg} \mathrm{GAE}{ }^{7}$. Hal ini didukung dengan teori bahwa polifenol memang banyak terkandung dalam kulit buah ${ }^{14}$. Dalam proses pelarutan kulit salak digunakan air sebagai pelarut karena senyawa fenol bersifat polar atau mudah larut di dalam air ${ }^{14}$.Selain itu penggunaan air sebagai pelarut tentunya mempertimbangkan agar mudahnya pengaplikasian dimasyarakat jika nantinya kulit salak dikembangkan sebagai suatu produk minuman fungsional berbasis kulit salak.

Pada formulasi 2 gram kulit salak dengan $200 \mathrm{ml}$ air hanya dapat menghasilkan total fenol sebesar $10.86 \pm$ $0.587 \mathrm{mg} / \mathrm{L}$ GAE. Hal tersebut menandakan hanya sebesar itulah kandungan fenol pada kulit salak yang mampu terekstrak dengan maksimal. Penurunan nilai total fenol dengan kandungan 20, 30 dan 40 gram kulit salak dapat disebabkan oleh senyawa fenol yang terkandung dalam kulit salak tidak dapat larut atau terekstrak sempurna dengan 200 
ml air (setara dengan segelas air) atau dapat dikatakan larutan tersebut lewat jenuh. Larutan lewat jenuh merupakan larutan yang mengandung solute berlebihan sehingga terdapat solute yang tidak terlarut ${ }^{19}$. Sehingga dapat diasumsikan senyawa fenolnya masih berada di dalam kulit salaknya dan belum terlarut maksimal. Maka dari itu formulasi rebusan kulit salak terbaik adalah formulasi 10 gram dengan $200 \mathrm{ml}$ air.

Dalam penelitian ini dilakukan juga uji organoleptik terhadap beberapa formulasi rebusan kulit salak tersebut. Berdasarkan hasil pengujian yang dilakukan pada 25 orang di Jurusan Analis Kesehatan Poltekkes Denpasar, didapatkan hasil yaitu tingkat kesukaan tertinggi diperoleh oleh formulasi kedua baik dari segi warna, rasa, aroma dan penerimaan keseluruhan. Mayoritas panelis memilih formulasi tersebut karena memiliki warna yang tidak terlalu bening ataupun pekat karena penambahan kulit salak yang tidak terlalu sedikit ataupun terlalu banyak, aroma yang harum dengan rasa yang tidak terlalu pahit maka dari itu lebih cocok jika nantinya dijadikan sebuah minuman. Kandungan polifenol didalam kulit salak itulah yang menyebabkan timbulnya aroma wangi yang menyegarkan. Dimana tumbuhan atau buah-buahan yang mengandung polifenol akan memiliki aroma yang harum dan rasa yang menyegarkan ${ }^{20}$.

Di Bali sentra penghasil buah salak adalah Kabupaten Karangasem dengan produksi terbesarnya berada di Desa Sibetan yaitu sebuah desa di Kecamatan Bebandem, Karangasem. Pengolahan berbahan salak tentunya sangat diperlukan selain untuk mengurangi kerugian saat musim panen, juga untuk meningkatkan nilai ekonominya. Pengolahan berbahan salak di desa ini baru hanya sebatas daging buah dan bijinya saja saja. Kulit dari salak tersebut berdasarkan hasil observasi dan keterangan dari kelompok tani setempat belum dimanfaatkan padahal banyak kandungan bermanfaat yang terkandung didalam kulit salak tersebut yang salah satunya adalah senyawa polifenol yang dapat sebagai antikanker. Sedikitnya terdapat 5 mekanisme aktivitas antikanker dari polifenol. Pertama, kemampuan antioksidan dari polifenol dapat melindungi sel dari kerusakan DNA dengan membersihkan sel dari radikal bebas (Reactive Oxygen Species / ROS). Kedua, polifenol memodulasi protein yang berperan dalam jalur transduksi signal seperti activator protein 1 (AP-1), mitogen-activated protein kinase (MAPK), phosphatidylinositol 3-kinase (PI 3'-K), p70S6-K dan Akt. Ketiga, polifenol mengurangi aktivitas dari tyrosine kinase 
I DG Aditya Satria Darma Putra, dkk., ANALISIS TOTAL FENOL PADA BERBAGAI FORMULASI REBUSAN KULIT SALAK BALI SIBETAN KARANGASEM SEBAGAI MINUMAN FUNGSIONAL

receptors (PDGF-R $\beta, \quad$ EGF-R) yang berperan dalam proliferasi ganas dari sel tumor. Keempat, polifenol menginduksi apoptosis pada sel tumor. Kelima, polifenol mengatasi resistensi multiobat dengan memblok efluks $P$-glycoprotein (Pgp) terhadap obat-obat antikanker ${ }^{21}$. Berdasarkan hal tersebut kulit salak yang selama ini dibuang begitu saja jika diolah dengan baik tentunya memiliki berbagai manfaat selain sebagai salah satu cara penanggulangan limbah, juga memiliki kandungan-kandungan yang baik bagi kesehatan salah satunya yaitu polifenolnya. Sehingga kulit salak ini dapat dikembangkan menjadi minuman fungsional yang nantinya dapat dikenal sebagai minuman herbal berbasis kulit salak.

\section{SIMPULAN DAN SARAN}

\section{Simpulan}

1. Nilai total fenol rebusan kulit salak Bali Sibetan Karangasem yang tertinggi adalah formulasi 10 gram kulit salak dengan $200 \mathrm{ml}$ air yaitu $13.79 \pm 0.756 \mathrm{mg} / \mathrm{L} \mathrm{GAE}$

2. Hasil uji organoleptik rebusan kulit salak yang terbaik adalah formulasi 10 gram kulit salak dengan $200 \mathrm{ml}$ air karena memiliki warna, rasa, aroma dan penerimaan keseluruhan yang pas dan cocok dijadikan sebagai sebuah minuman.

\section{Saran}

1. Bagi petani setempat disarankan untuk melakukan pengembangan terhadap pengolahan berbahan salak, salah satunya adalah pada bagian kulitnya Disarankan formulasi yang digunakan adalah 10 gram kulit salak dengan 200 ml air karena selain memiliki total fenol yang maksimal, juga memiliki warna, aroma dan rasa yang terbaik diantara formulasi lainnya. Dapat juga ditambahkan Bahan Tambahan Pangan berupa gula untuk menambah cita rasa dari produk minuman tersebut.

2. Untuk masyarakat dapat menjadikan rebusan kulit salak sebagai minuman alternatif yang baik bagi kesehatan untuk pencegahan dini berbagai penyakit degeneratif.

\section{DAFTAR PUSTAKA}

1. Tika, I N., I G. A. T. Agustina, dan G. A. Yuniartaa. IbM Salak di Desa Sibetan Bali. http://lemlit.undiksha.ac.id/media/1 280._i_nyoman_Tikadkk.,m (diakses pada 27 november 2015). 2013. 
2. Astawan, A-Z Ensiklopedia Gizi Pangan Untuk Keluarga. Jakata : Dian Rakyat, M. 2009.

3. Lestari, R., G. Elbert, dan S.H. Keil. Fruit Quality Changes of Salak "Pondoh" Fruits (Salacca zalacca (Gaertn.) Voss) during Maturation and Ripening ; Journal of Food Research: Vol. 2, No. 1. http://www.ccsenet.org/journal/inde x.php/jfr/article/viewFile/22743/15 394 (diakses pada 30 november 2015). 2013

4. Vauzour, D., A. R. Mateos, G. Corona, dan J.P.E. Spencer. Polyphenol and Human Health : Prevention of Diseases and Mechanism of Action : Journal nutrient. ISSN 2072-6643. 2010.

5. Dhianawaty, D., Ruslin. Kandungan Total Polifenol Dan Aaktovitas Antioksidan Dari Ekstrak Metanol Akar Imperata cylindrica (L) Beauv (Alang Alang). MKB. Volume 47 (1). http://journal.fk.unpad.ac.id/index.p hp/mkb/article/viewFile/398/pdf_1 61. (diakses pada tanggal 24 januari 2016). 2015.

6. Leontowicz, H., M. Leontowicz, J. Drzewiecki, dan S. Poovarodom. Bioactive properties of Snake Fruit (Salacca edulis Reinw) and
Mangosteen

(Garcinia

mangostana) and their Influence on

Plasma Lipid Profile and Antioxidant activity in Rats Fed

Cholesterol. European Food

Research and Technology 223 : 697-703.

http://link.springer.com/article/10.1 007\%2Fs00217-006-0255-7.(

Diakses pada 27 november 2015). 2006.

7. Ariviani, S., N.H.R. Parnanto. Kapasitas Antioksidan Buah Salak (Salacca Edulis Reinw) Kultivar Pondoh, Nglumut Dan Bali Serta Korelasinya Dengan Kadar Fenolik Total Dan Vitamin C : Agritech.Vol.33. No.3. Agustus 2013. 2013.

8. Sarmiati, N. N., N.W. Suparmi, dan N.M.A. Trisnawati. Upaya Pelestarian Salak Gula Pasir Melalui Pelatihan Dan Pembinaan Petani Dengan Pencangkokan Di Desa Sibetan. Jurnal Bestari. Volume 42. 2009.

9. Triadi, N. Tinjauan Kapasitas Antioksidan Madu Salak di Desa Sibetan, Kecamatan Bebandem, Kabupaten Karangasem. Denpasar : Jurusan Analis Kesehatan Poltekkes Denpasar. 2015. 
10. Sahputra, F., M. Potensi Ekstrak Kulit dan Daging Buah Salak Sebagai Antidiabetes. Bogor: Program Studi Biokimia Fakultas MIPA. 2008.

11. Dhyanaputri, I G. A., I W. Karta, dan L.A. Wilan. Analisis Kandungan Gizi Ekstrak Kulit Salak Produksi Kelompok Tani Abian Salak Desa Sibetan Sebagai Upaya Pengembangan Potensi Produk Pangan Lokal . Denpasar : Politeknik Kesehatan Denpasar. 2015.

12. Yusniarti, F., A.D.Y. Montolalu, dan F. Mentang. Kandungan Total Fenol Dalam Rumput Laut (Caulerpa racemosa ) Yang Berpotensi Sebagai Antioksidan.http://ejournal.unsrat.a c.id/index.php/jmthp/article/viewFi le/1859/1468. (diakses pada 27 november 2015). 2013.

13. Handayani, S., R. Arianingrum, dan W. Haryadi. Aktivitas Antioksidan dan Antikanker Turunan Benzalseton. Yogyakarta : Fakultas Matematika dan Ilmu Pengetahuan Alam Universitas Negeri Yogyakarta. 2014.

14. Winarti, S. Makanan Fungsional. Yogyakarta : Graha Ilmu. 2010.
15. Notoatmodjo, S. Metodologi Penelitian Kesehatan. Jakarta : Rineka Cipta

16. Sugiyono.. Statistika Untuk Penelitian. Bandung : Alfabeta 2013.

17. Hendri, Z., dan R. Arianingrum. Pengembangan Teknologi Pengawetan Kulit Salak Untuk Bahan Produk Seni Kerajinan. Jurnal Penelitian Saintek: Vol.15, No.2. 2010.

18. Musthafavi, Z. Analisis Kapasitas Antioksidan Dan Kandungan Total Fenol Pada Buah. http://repository.ipb.ac.id (diakses pada 29 mei 2016). 2014.

19. Budiman, A. Farmasi Fisika Kelarutan. Online. http://blogs.unpad.ac.id. (Diakses pada 17 Juli 2016). 2011.

20. Kumalaningsih, S. 2006. Antioksidan Alami. Surabaya : Trubus Agrisarana

21. Ramadhan, P. Mengenal Antioksidan. Yogyakarta : Graha ilmu. 2015. 
